Article

\title{
Isolation of a Nitromethane Anion in the Calix-Shaped Inorganic Cage
}

\author{
Yuji Kikukawa ${ }^{1,2, *}$, Hiromasa Kitajima ${ }^{1}$, Sho Kuwajima ${ }^{1}$ and Yoshihito Hayashi ${ }^{1, *}$ \\ 1 Department of Chemistry, Graduate School of Natural Science and Technology, \\ Kanazawa University Kakuma, Kanazawa 920-1192, Japan; h.kitajima8923@stu.kanazawa-u.ac.jp (H.K.); \\ skuwaji@stu.kanazawa-u.ac.jp (S.K.) \\ 2 Japan Science and Technology Agency, Precursory Research for Embryonic Science and Technology, \\ 4-1-8 Honcho, Kawaguchi 332-0012, Japan \\ * Correspondence: kikukawal@se.kanazawa-u.ac.jp (Y.K.); hayashi@se.kanazawa-u.ac.jp (Y.H.); \\ Tel.: +81-76-264-5691 (Y.H.)
}

Academic Editor: Mario Berberan-Santos and Paula M. Marcos Received: 30 October 2020; Accepted: 27 November 2020; Published: 1 December 2020

\begin{abstract}
A calix-shaped polyoxometalate, $\left[\mathrm{V}_{12} \mathrm{O}_{32}\right]^{4-}(\mathbf{V 1 2})$, stabilizes an anion moiety in its central cavity. This molecule-sized container has the potential to control the reactivity of an anion. The highly-reactive cyanate is smoothly trapped by $\mathbf{V 1 2}$ to form $\left[\mathrm{V}_{12} \mathrm{O}_{32}(\mathrm{CN})\right]^{5-}$. In the $\mathrm{CH}_{3} \mathrm{NO}_{2}$ solution, cyanate abstracts protons from $\mathrm{CH}_{3} \mathrm{NO}_{2}$, and the resultant $\mathrm{CH}_{2} \mathrm{NO}_{2}{ }^{-}$is stabilized in V12 to form $\left[\mathrm{V}_{12} \mathrm{O}_{32}\left(\mathrm{CH}_{2} \mathrm{NO}_{2}\right)\right]^{5-}\left(\mathbf{V 1 2}\left(\mathrm{CH}_{2} \mathrm{NO}_{2}\right)\right)$. A crystallographic analysis revealed the double-bond characteristic short bond distance of $1.248 \AA$ between the carbon and nitrogen atoms in the nitromethane anion in V12. ${ }^{1} \mathrm{H}$ and ${ }^{13} \mathrm{C}$ NMR studies showed that the nitromethane anion in V12 must not be exchanged with the nitromethane solvent. Thus, the V12 container restrains the reactivity of anionic species.
\end{abstract}

Keywords: calixarene-like structure; polyoxometalates; nitronate; crystal structure; host-guest chemistry; anion receptor

\section{Introduction}

Calixarene possesses a rigid conformation with a broader hydrophobic upper rim, a narrow hydrophilic lower rim, and a central annulus. Due to this attractive architecture, the host-guest chemistry of calixarene has been developed [1-4]. It can include various chemical moieties of neutral molecules, cations, and anions through hydrophobic, cation $-\pi$, anion $-\pi$, and hydrogen-bonding interactions [5]. The host property is finely tuned by the functional modification of the upper rim and/or the lower rim. Calixarene is utilized in various fields of science, such as catalysis, sensors, functional materials, analytical chemistry, electrochemistry, photochemistry, biochemistry, and pharmacy [6-11]. The cavity diameters, considering the van der Waals radii, around the upper rim of calix [4] arenes and calix [6] arenes are $3.8 \AA$ and $5.0 \AA$, respectively [12].

Polyoxometalates are a large family of metal-oxide cluster anions. They show several unique properties related to their well-defined structures [13-15]. Tungsten- and molybdenum-based polyoxometalates adopt lacunary structures by removing constituent elements. The lacunary type polyoxometalates act as inorganic multidentate ligands to stabilize several metal or metal-oxide cores. On the other hand, vanadium-based polyoxometalates formed by the condensation of $\mathrm{VO}_{5}$ square pyramids stabilize anionic moiety at the center of their clusters $[16,17]$. Up to now, various kinds of anions have been included in the vanadium-based polyoxometalates. Most anion-including polyoxometalates are sphere structures. [18] Although each electrophilicity directed to the base of the $\mathrm{VO}_{5}$ square pyramid is weak, the electrophilicity is strengthened by the condensation of 
the $\mathrm{VO}_{5}$ pyramids oriented to the center of a sphere to stabilize an anion. The distance between the central anion and its nearest neighbor vanadium is far from bonding distances, showing that the central anion is floating in the container. Among polyoxometalates composed of $\mathrm{VO}_{5}$ square pyramids, a 'calix'-shaped dodecavanadate $\left[\mathrm{V}_{12} \mathrm{O}_{32}\right]^{4-}(\mathbf{V 1 2})$ is known [19-30]. The broader upper rim consists of eight edge-shared $\mathrm{VO}_{5}$ pyramids, with a $4.4 \AA$ cavity entrance and a narrow lower rim consisting of four vertex-shared $\mathrm{VO}_{5}$ pyramids (Figure 1). This attractive structure was first reported by Day et al. in 1989 [19]. In the initial stage of the V12 chemistry, the utility is limited to the guest exchange among nitriles because of the strong affinity between the nitrile group and the V12 container [20-22]. Recently, we have developed the host-guest chemistry of V12 [23-29]. By avoiding the usage of the nitrile group in the synthetic procedure by controlling the oxidation state of the vanadium sources, V12 with guest-exchangeability to various electron-rich groups can be prepared [25]. In addition, the guest-removal from V12 is successfully accomplished [28]. Importantly, during the guest removal, even in the solid state, one of the $\mathrm{VO}_{5}$ square pyramids of lower rim is flipped, and an oxygen atom is located at the center of the V12 to fill the cavity. The structure is retrieved by the exposure to the guest vapor, such as acetonitrile, nitromethane, dichloromethane, 1,2-dichloroethane, bromomethane, $\mathrm{CO}_{2}$, or $\mathrm{Br}_{2}$. Thus, $\mathbf{V 1 2}$ can be categorized as one of the guest-responsible Supramolecular Association-Dissociation Switches [3]. In the case of $\mathrm{Br}_{2}$, $\mathrm{Br}_{2}$ inserted into V12 is polarized due to the unique charge distribution of the inside of V12, and the peak of the $\mathrm{Br}-\mathrm{Br}$ vibration is detected in IR at $185 \mathrm{~cm}^{-1}$ [29]. Furthermore, the stabilization of several kinds of anions in V12 has been reported [25-27]. The most interesting example is $\mathrm{NO}^{-}$-including V12 [30]. While a standard chemistry text book introduces the electron structure of an anionic nitrogen monoxide, the isolation of anionic $\mathrm{NO}^{-}$is very rare due to its stability and short life under normal experimental conditions.

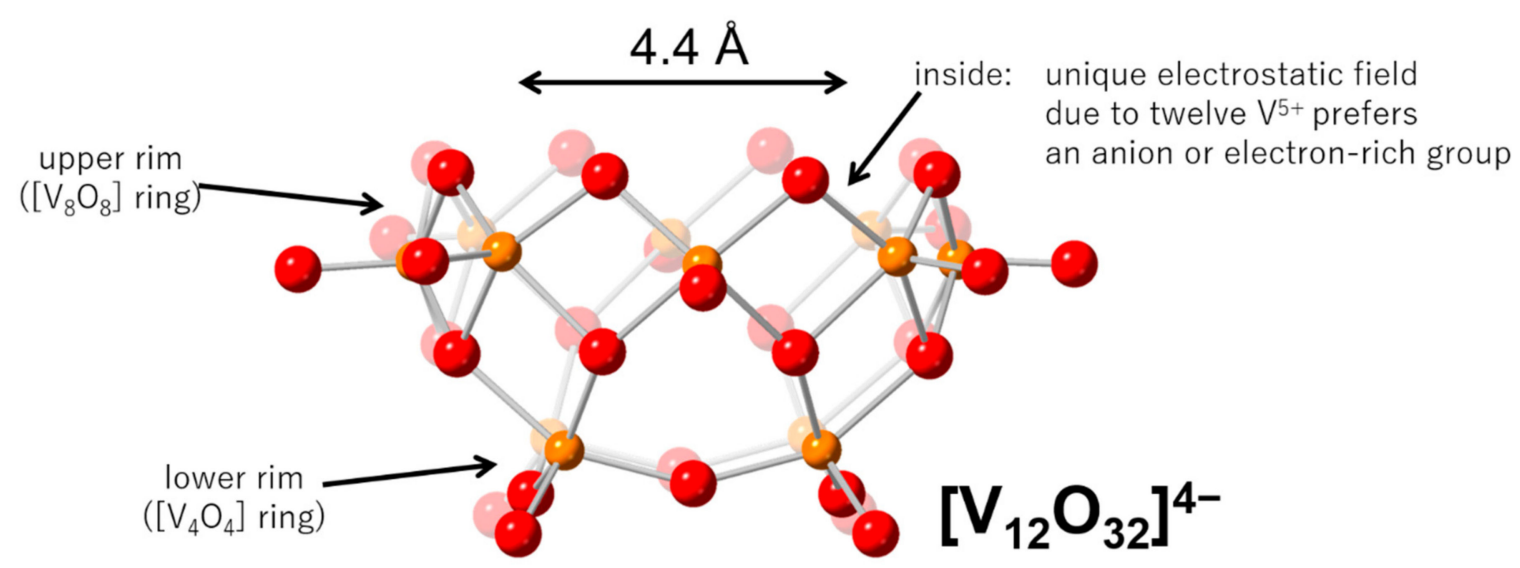

Figure 1. Schematic representation of a dodecavanadate. The red and orange spheres represent oxygen and vanadium atoms, respectively.

Cyanide shows high nucleophilicity and acts as a ligand for several kinds of metal cations. The high nucleophilicity also makes it act as efficient Brønsted and Lewis base catalysts [31-34]. The discrete cyanide catalyzes the cyanosilylation of aldehydes, deprotonation, deacetylation, and Michael addition reactions. In this report, the host-guest chemistry of V12 is applied to the reaction inhibitor. The addition of V12 during the catalytic reaction with cyanide quenches the reaction to form cyanide-including V12. Successively, the guest exchange reaction proceeds to form nitromethane-anion-including V12 $\left(\left[\mathrm{V}_{12} \mathrm{O}_{32}\left(\mathrm{CH}_{3} \mathrm{NO}_{2}\right)\right]^{4-}, \mathbf{V 1 2}\left(\mathrm{CH}_{2} \mathrm{NO}_{2}\right)\right)$ in nitromethane. The crystal structure and ${ }^{1} \mathrm{H}$ and ${ }^{13} \mathrm{C}$ NMR spectra are also discussed. 


\section{Results and Discussion}

\subsection{Reactivity of Cyanide and the Effect of the Addition of V12}

Tetraethylammmonium cyanide $\left\{\mathrm{Et}_{4} \mathrm{~N}\right\} \mathrm{CN}$ is commercially available and stable. Bare cyanide in $\left\{\mathrm{Et}_{4} \mathrm{~N}\right\} \mathrm{CN}$ shows higher reactivity than that in metal cyanide complexes. In the presence of $1 \mathrm{~mol} \%$ of $\left\{\mathrm{Et}_{4} \mathrm{~N}\right\} \mathrm{CN}$, the reaction of acetophenone and trimethylsilyl cyanide gave the corresponding cyanohydrin trimethylsilyl ether with a 93\% yield in $5 \mathrm{~min}$ (Figure 2). The turnover frequency reaches $19 \mathrm{~min}^{-1}$. This value is the highest level among the previous reports [35-38]. By the addition of V12(NM) into the reaction solution, V12(NM) was easily decomposed due to the formation of electrophilic trimethylsilyl cations and/or the successive formation of nucleophilic cyanide.

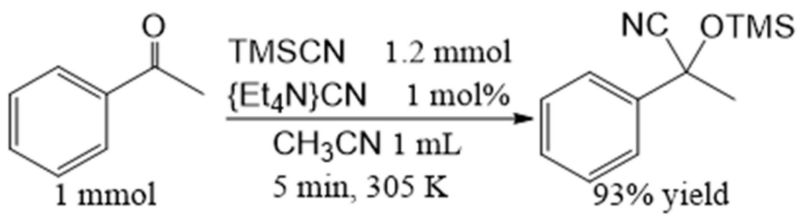

(a)

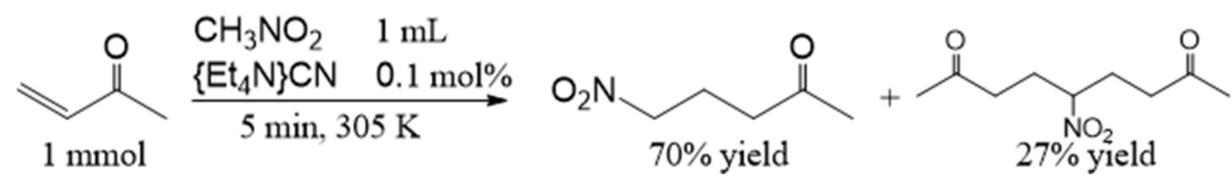

(b)

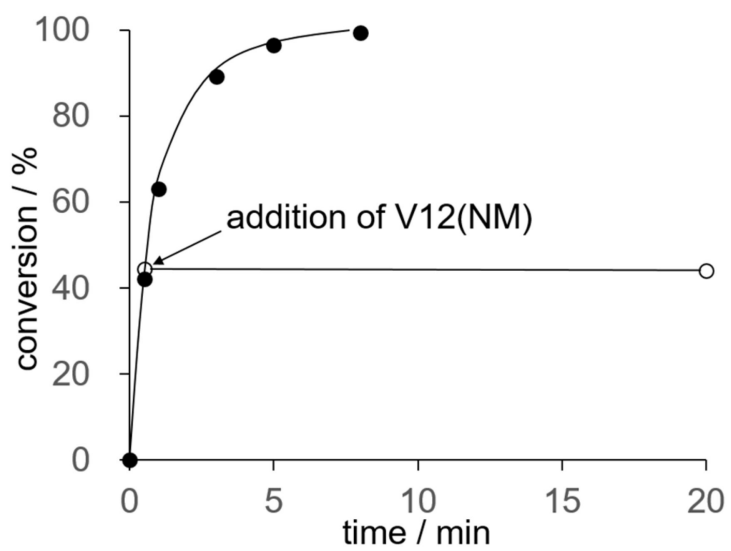

(c)

Figure 2. Catalytic performance of $\left\{\mathrm{Et}_{4} \mathrm{~N}\right\} \mathrm{CN}$ for (a) cyanosilylation, (b) Michael addition, and (c) time course profiles of Michael addition and the effect of the addition of V12(NM). One equivalent of V12(NM) respective to $\left\{\mathrm{Et}_{4} \mathrm{~N}\right\} \mathrm{CN}$ was added $30 \mathrm{~s}$ after the reaction started.

Cyanide also catalyzes Michael addition [34]. In the presence of $0.1 \mathrm{~mol} \%$ of $\left\{\mathrm{Et}_{4} \mathrm{~N}\right\} \mathrm{CN}$, the conversion of methyl vinyl ketone in nitromethane reached $97 \%$ in $5 \mathrm{~min}$, to give 5-nitro-2-pentanone with a $70 \%$ yield and 5-nitro-2,8-nonanedione with a $27 \%$ yield (Figure 2 ). This reaction proceeded as follows. Nitromethane was deprotonated by the cyanide catalyst, and the reactive nitronate attacked the beta carbon to give the products. After $30 \mathrm{sec}$, about $40 \%$ of the methyl vinyl ketone was converted under the catalytic condition. By the addition of one equivalent of $\mathbf{V 1 2}(\mathrm{NM})$ with respect to $\left\{\mathrm{Et}_{4} \mathrm{~N}\right\} \mathrm{CN}$ into the reaction solution after $30 \mathrm{sec}$, the reaction immediately stopped (Figure 2). Even if ten times the amounts of the catalyst and V12(NM) were used, the reaction did not proceed. 
The ${ }^{51} \mathrm{~V}$ NMR of the reaction solution was measured. The results described below were beyond our imagination. From our previous report, it was assumed that the reaction was quenched by the incorporation of cyanide into the V12. However, this was not all. After $30 \mathrm{~min}$ from the addition of V12(NM) into the reaction solution, the ${ }^{51} \mathrm{~V}$ NMR showed $\mathrm{t}$ three signals at $-564,-572$, and $-578 \mathrm{ppm}$, which are different signals from those of cyanido-including V12 $\left(\left[\mathrm{V}_{12} \mathrm{O}_{32}(\mathrm{CN})\right]^{5-}, \mathbf{V 1 2}(\mathrm{CN})\right)$ (Figure S1). This spectrum is also different from that of V12(NM). The spectrum most closely resembles that of acetate-including V12 $\left(\left(\left[\mathrm{V}_{12} \mathrm{O}_{32}\left(\mathrm{CH}_{3} \mathrm{CO}_{2}\right)\right]^{5-}, \mathrm{V12}(\mathrm{OAc})\right)\right.$, with three signals at -567 (sharp), -578 (broad), and -585 ppm (broad) (Figure S2).

The ${ }^{51} \mathrm{~V}$ NMR spectrum was monitored without the addition of methyl vinyl ketone (Figure S3). Compound V12(NM) in nitromethane showed three signals at $-591,-596$, and $-606 \mathrm{ppm}$. Through the addition of $\left\{\mathrm{Et}_{4} \mathrm{~N}\right\} \mathrm{CN}$, three signals at $-578,-586$, and $-599 \mathrm{ppm}$ due to $\mathrm{V12}(\mathrm{CN})$ were observed. With time, the intensity of the signals of V12(CN) decreased, and that of the three signals at $-564,-572$, and $-578 \mathrm{ppm}$ increased. The cold-spray ionized mass (CSI-MS) spectrum of the nitromethane solution of V12(CN) showed peaks at 1930 of $\left\{\left(\mathrm{Et}_{4} \mathrm{~N}\right)_{6}\left[\mathrm{~V}_{12} \mathrm{O}_{32}(\mathrm{CN})\right]\right\}^{+}$(Figure S4). With time, this peak intensity decreased and the intensity of the peak at 1964 assignable to $\left\{\left(\mathrm{Et}_{4} \mathrm{~N}\right)_{6}\left[\mathrm{~V}_{12} \mathrm{O}_{32}\left(\mathrm{CH}_{2} \mathrm{NO}_{2}\right)\right]\right\}^{+}$increased. Considering these results and the reaction mechanism, by the addition of V12(NM), cyanide was actually trapped in $\mathbf{V 1 2}$ to form $\mathrm{V12}(\mathrm{CN})$; the successive deprotonation of nitromethane proceeded, and $\mathrm{CH}_{2} \mathrm{NO}_{2}{ }^{-}$was stabilized in $\mathbf{V 1 2}$ to form $\left[\mathrm{V}_{12} \mathrm{O}_{32}\left(\mathrm{CH}_{2} \mathrm{NO}_{2}\right)\right]^{5-}\left(\mathbf{V 1 2}\left(\mathbf{C H}_{2} \mathbf{N O}_{2}\right)\right)$. Thus, the reaction of methyl vinyl ketone and $\mathrm{CH}_{3} \mathrm{NO}_{2}$ with $\left\{\mathrm{Et}_{4} \mathrm{~N}\right\} \mathrm{CN}$ catalyst stopped at the step of the formation of $\mathrm{CH}_{2} \mathrm{NO}_{2}^{-}$in V12.

\subsection{Crystal Strucuture and Charactorization}

Fortunately, we can obtain crystals suitable for the X-ray structure analysis by the cation exchange from $\mathrm{Et}_{4} \mathrm{~N}^{+}$to $\mathrm{Me}_{4} \mathrm{~N}^{+}$(Table S1, Figure 3). The anion structure exhibits the typical V12 structure with the guest moiety of $\mathrm{CH}_{2} \mathrm{NO}_{2}{ }^{-}$in the concave. This is the first report on the crystal structure of nitromethane anions, as far as we know. Four $\mathrm{CH}_{3} \mathrm{NO}_{2}$ as crystalline solvents and five $\left\{\mathrm{Me}_{4} \mathrm{~N}\right\}^{+}$ were determined, supporting the theory that the moiety in V12 is a -1 charged anion. These results agreed well with the elemental and thermogravimetric analyses. In the case of neutral $\mathrm{CH}_{3} \mathrm{NO}_{2}$ as a guest, one of the oxygen atoms of the nitro group is inserted into the cavity, and the other oxygen is located at the same level of the entrance oxygen atoms of V12 (Figure S5). On the other hand, two oxygen atoms of $\mathrm{CH}_{2} \mathrm{NO}_{2}{ }^{-}$were packed into the concave of V12. The shortest distance between the nearest vanadium atom and an oxygen atom of $\mathrm{CH}_{2} \mathrm{NO}_{2}{ }^{-}$is $2.538(6) \AA$, showing that $\mathrm{CH}_{2} \mathrm{NO}_{2}{ }^{-}$ is not directly bonded to vanadium centers. Although the visual aspect of $\mathbf{V 1 2}\left(\mathbf{C H}_{\mathbf{2}} \mathbf{N O}_{\mathbf{2}}\right)$ is similar to that of V12(OAc), each bond distance in the guest is different. $\mathrm{CH}_{2} \mathrm{NO}_{2}{ }^{-}$possesses a $1.255(11) \AA$ of $\mathrm{C}-\mathrm{N}$ bond, and 1.325(8) $\AA$ and 1.313(8) $\AA$ of $\mathrm{N}-\mathrm{O}$ bonds, while ${ }^{-} \mathrm{OAc}$ possesses a 1.506(5) $\AA$ of $\mathrm{C}-\mathrm{C}$ bond, and 1.257(4) $\AA$ and 1.260(4) $\AA$ of $\mathrm{C}-\mathrm{O}$ bonds. Generally, a nitromethane anion exhibits resonance structures: anion charge locates on a carbon atom with a single $\mathrm{C}-\mathrm{N}$ bond, and anion charge locates on oxygen atoms with a double $\mathrm{C}=\mathrm{N}$ bond. The 1.255(11) $\AA$ bond distance of the $\mathrm{C}-\mathrm{N}$ of $\mathrm{CH}_{2} \mathrm{NO}_{2}{ }^{-}$shows the composition of a double bond between carbon and nitrogen atoms. During the above mentioned catalytic reaction, the formation of more reactive ${ }^{-} \mathrm{CH}_{2}-\mathrm{NO}_{2}$ was restrained by the inclusion of $\mathrm{CH}_{2} \mathrm{NO}_{2}{ }^{-}$in $\mathbf{V 1 2}$, and the reaction stopped.

The ${ }^{51} \mathrm{~V}$ NMR spectrum of $\mathbf{V 1 2}\left(\mathbf{C H}_{\mathbf{2}} \mathbf{N O}_{2}\right)$ in nitromethane is maintained for more than $60 \mathrm{~min}$. In order to determine the ${ }^{13} \mathrm{C}$ NMR for the nitromethane anion in V12, ${ }^{13} \mathrm{C}$-enriched nitromethane-anion-including V12 was prepared. The ${ }^{51}$ VNMR spectrum showed isotope shift (Figure S1) [39]. The ${ }^{13} \mathrm{C}$ NMR spectrum showed a peak at $109.3 \mathrm{ppm}$ of nitromethane anions, in addition to peaks at 52.2 and $6.5 \mathrm{ppm}$ of $\left\{\mathrm{Et}_{4} \mathrm{~N}\right\}^{+}$. In an off resonance-decoupled ${ }^{13} \mathrm{C}$, a peak at $109.2 \mathrm{ppm}$ was tripled, showing that two protons are attached to the carbon (Figure S6) $[40,41]$. The peak intensity of the nitromethane anion is maintained for more than $60 \mathrm{~min}$, suggesting that the included ${ }^{13} \mathrm{C}$-nitromethane anion is not exchanged with the ${ }^{12} \mathrm{C}$-one derived from the nitromethane solvent. In the ${ }^{1} \mathrm{H}$ NMR spectra in $\mathrm{CD}_{3} \mathrm{NO}_{2}$, a peak at $5.27 \mathrm{ppm}$ due to the nitromethane anion was detected 
(Figure S7). The peak intensity is retained for more than $60 \mathrm{~min}$, showing that the proton exchange reaction between the included nitromethane anion and nitromethane solvent does not proceed.

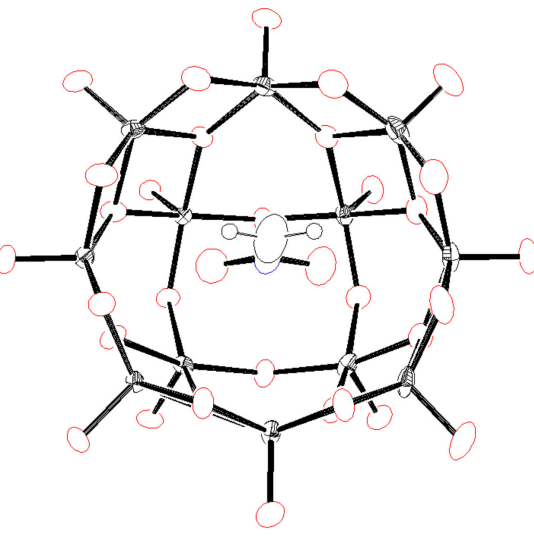

(a)

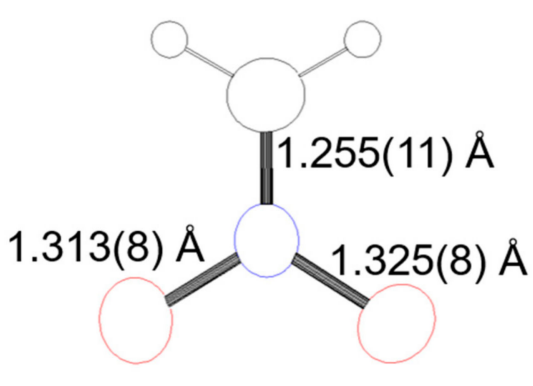

(b)

Figure 3. Ortep representations of (a) an anion section of $\mathbf{V 1 2}\left(\mathrm{CH}_{2} \mathrm{NO}_{2}\right)$ and (b) a $\mathrm{CH}_{2} \mathrm{NO}_{2}{ }^{-}$fragment in the cavity of V12. The black octant shading and spheres represent vanadium and hydrogen atoms, respectively. The red, blue, and black boundaries represent oxygen, nitrogen, and carbon atoms, respectively.

\section{Materials and Methods}

All of the reagents were obtained from commercial suppliers and were used without further purification unless otherwise noted. The solvents for the NMR measurements of the authentic V12 $\left(\mathrm{CH}_{2} \mathrm{NO}_{2}\right)$ were dehydrated by molecular sieve $4 \mathrm{~A}$. The V12(NM) and V12(CN) were synthesized following the literature [26].

For the synthesis of $\left\{\mathrm{Et}_{4} \mathrm{~N}\right\}_{5}\left[\mathrm{~V}_{12} \mathrm{O}_{32}\left(\mathrm{CH}_{2} \mathrm{NO}_{2}\right)\right]$ and $\left\{\mathrm{Me}_{4} \mathrm{~N}\right\}_{5}\left[\mathrm{~V}_{12} \mathrm{O}_{32}\left(\mathrm{CH}_{2} \mathrm{NO}_{2}\right)\right]$, the tetraethyl salt of V12(CN) $(100 \mathrm{mg}, 0.056 \mathrm{mmol})$ was dissolved in $5 \mathrm{~mL}$ of $\mathrm{CH}_{3} \mathrm{NO}_{2}$ and stirred for $1 \mathrm{~h}$. The addition of an excess amount of diethyl ether with vigorous stirring gave a brown powder of $\left\{\mathrm{Et}_{4} \mathrm{~N}\right\}_{5}\left[\mathrm{~V}_{12} \mathrm{O}_{32}\left(\mathrm{CH}_{2} \mathrm{NO}_{2}\right)\right]$. The precipitates were collected by filtration and dried (85 $\mathrm{mg}, 83 \%$ yield). ${ }^{51} \mathrm{~V} \mathrm{NMR}$ (in $\mathrm{CD}_{3} \mathrm{NO}_{2}$ ); $\delta=-564,-572$, and $-578 \mathrm{ppm} .{ }^{1} \mathrm{H} \mathrm{NMR}$ (in $\mathrm{CD}_{3} \mathrm{NO}_{2}$ ); $\delta=5.28$ (s), 3.40 (q), and 1.36 (t) ppm. ${ }^{13} \mathrm{C} \mathrm{NMR} \mathrm{(in} \mathrm{CD}_{3} \mathrm{NO}_{2}$ ); $\delta=109.2,52.2$ and $6.5 \mathrm{ppm}$. The peak due to $\mathrm{CH}_{2} \mathrm{NO}_{2}$ was only observed by using a ${ }^{13} \mathrm{C}$-enriched carbon source. ${ }^{13} \mathrm{C}$-enriched $\left[\mathrm{V}_{12} \mathrm{O}_{32}\left({ }^{13} \mathrm{CH}_{2} \mathrm{NO}_{2}\right)\right]^{5-}$ was obtained by the dissolution of $\operatorname{V12}(\mathrm{CN})$ into ${ }^{13} \mathrm{CH}_{3} \mathrm{NO}_{2}$. IR (Attenuated Total Reflection (ATR) without ATR correction): 2983, 2949, 2882, 1927, 1642, 1547, 1481, 1455, 1392, 1392, 1305, 1254, 1173, 1102, 1056, 1035, 973, 902, 853, 831, 750, 699, 628, 543, and $511 \mathrm{~cm}^{-1}$ (Figure S8). For the crystallographic analysis, tetramethylammonium salt was prepared. The tetraethylammonium salt of V12(CH2NO2) (91.7 mg, $0.05 \mathrm{mmol}$ ) was dissolved in $2 \mathrm{~mL}$ nitromethane. To this solution, $3 \mathrm{~mL}$ nitromethane solution of $\left\{\mathrm{Me}_{4} \mathrm{~N}\right\} \mathrm{ClO}_{4}(43.4 \mathrm{mg}, 0.25 \mathrm{mmol})$ was added. The immediately-formed precipitates were removed by filtration and stood at $5{ }^{\circ} \mathrm{C}$ for 2 days. Elemental analysis calcd for $\left\{\mathrm{Me}_{4} \mathrm{~N}\right\}_{5}\left[\mathrm{~V}_{12} \mathrm{O}_{32}\left(\mathrm{CH}_{2} \mathrm{NO}_{2}\right)\right] \cdot 4 \mathrm{CH}_{3} \mathrm{NO}_{2}\left(\mathrm{C}_{25} \mathrm{H}_{74} \mathrm{~N}_{10} \mathrm{O}_{42} \mathrm{~V}_{12}\right):$ C $16.70 \%, \mathrm{H} 4.15 \%$, N 7.79\%; found: C $16.85 \%$, H 4.17\%, N 7.32\%. The Thermogravimetric analysis data showed 14\% mass-decreasing (the desorption of four $\mathrm{CH}_{3} \mathrm{NO}_{2}$ as crystalline solvent) by $180{ }^{\circ} \mathrm{C}$.

The catalytic reaction was carried out as follows. Into a screw-capped test tube, $1 \mathrm{mmol}$ substrate, $1 \mathrm{~mL}$ solvent, $\left\{\mathrm{Et}_{4} \mathrm{~N}\right\} \mathrm{CN}$ (catalyst) $1 \mathrm{~mol} \%$ for cyanosililation and $0.1 \mathrm{~mol} \%$ for Michael addition and naphthalene (internal standard) were added and stirred at $800 \mathrm{rpm}$ at $305 \mathrm{~K}$.

The IR spectra were measured with the ATR method (Zn/Se prism) on a JASCO FT/IR-4200 spectrometer. The ${ }^{1} \mathrm{H},{ }^{13} \mathrm{C}$ and ${ }^{51} \mathrm{~V}$ NMR spectra were recorded on a JEOL JNM-LA400. The thermogravimetry data were collected on a Rigaku Thermo plus EVO2 instrument with a temperature sweep rate of $10^{\circ} \mathrm{C} / \mathrm{min}$ under $\mathrm{N}_{2}$ flow $(200 \mathrm{~mL} / \mathrm{min})$. The elemental analyses of $\mathrm{C}, \mathrm{H}$, 
and $\mathrm{N}$ were performed by the Research Institute for Instrumental Analysis at Kanazawa University. The GC analyses were performed on a Shimadzu GC-2014 with a flame ionization detector (FID) equipped with a InertCap Pure-WAX or ZB-WAXplus capillary column (internal diameter $=0.25 \mathrm{~mm}$, length $=30 \mathrm{~m})$.

The diffraction measurements of $\mathbf{V 1 2}\left(\mathrm{CH}_{2} \mathrm{NO}_{2}\right)$ were performed on a Bruker D8 VENTURE diffractometer with graphite monochromated $\mathrm{Cu} K \alpha$ radiation $(\lambda=1.54178 \AA)$. The data reduction and absorption correction were carried out using the APEX3 program [42]. The structural analyses were performed using APEX3 and WinGX [43]. The structures were refined by SHELXL-2013 [44]. The non-hydrogen atoms were refined anisotropically. The hydrogen atoms were positioned geometrically and refined using a riding model. The atoms in one of the tetramethylammoinium cations are restrained with a SIMU command. CCDC 2,041,581 contains the supplementary crystallographic data for this paper. These data can be obtained, free of charge, from The Cambridge Crystallographic Data Centre.

\section{Conclusions}

Calix-shaped dodecavanadate V12 acts as an efficient trap for the reactive anion species. By dissolving cyanide-including V12 in nitromethane, nitromethane is activated and the nitromethane anion-the reaction intermediate-is stabilized in V12, which enables the X-ray crystallographic analysis.

Supplementary Materials: Figure S1: ${ }^{51} \mathrm{~V}$ NMR spectra of the reaction mixture of methyl vinyl ketone (1 mmol), $\mathrm{CH}_{3} \mathrm{NO}_{2}(1 \mathrm{~mL}),\left\{\mathrm{Et}_{4} \mathrm{~N}\right\} \mathrm{CN}(10 \mu \mathrm{mol})$, and V12(NM) $(10 \mu \mathrm{mol})$ after $20 \mathrm{~min}$., Figure S2: ${ }^{51} \mathrm{~V}$ NMR spectra of (a) $\left[\mathrm{V}_{12} \mathrm{O}_{32}\left({ }^{13} \mathrm{CH}_{2} \mathrm{NO}_{2}\right)\right]^{5-}$, (b) $\mathbf{V 1 2}\left(\mathrm{CH}_{2} \mathrm{NO}_{2}\right)$, (c) V12(OAc), (d) V12(NM) and (e) V12(CN) in nitromethane, Figure S3: ${ }^{51} \mathrm{~V}$ NMR spectra of the dehydrated-nitromethane solution of (a) V12(NM), and $\left\{\mathrm{Et}_{4} \mathrm{~N}\right\} \mathrm{CN}(10 \mu \mathrm{mol})$, and V12(NM) $(10 \mu \mathrm{mol})$ after (b) $1 \mathrm{~min}$, (c) $5 \mathrm{~min}$, (d) $10 \mathrm{~min}$ and (e) $20 \mathrm{~min}$, Figure S4: CSI-MS spectra (positive mode) of the nitromethane solution of $\mathbf{V 1 2}(\mathbf{C N})$ (a) just after dissolution, (b) after $10 \mathrm{~min}$ and (c) after $30 \mathrm{~min}$, Figure S5: Anion structures of (a) V12 $\left(\mathrm{CH}_{2} \mathrm{NO}_{2}\right),($ b) V12(OAc), (c) V12(NM) and (d) V12(CN), Figure S6: (a) Decoupling and (b) off resonance-decoupled ${ }^{13} \mathrm{C}$ NMR spectra of $\mathbf{V 1 2}\left(\mathbf{C H}_{\mathbf{2}} \mathbf{N O}_{\mathbf{2}}\right)$ in $\mathrm{CD}_{3} \mathrm{NO}_{2}$, Figure S7: ${ }^{1} \mathrm{H}$ NMR spectrum of $\mathbf{V 1 2}\left(\mathrm{CH}_{2} \mathrm{NO}_{2}\right)$ in $\mathrm{CD}_{3} \mathrm{NO}_{2}$, Figure S8: IR spectrum of $\mathbf{V 1 2}\left(\mathrm{CH}_{2} \mathrm{NO}_{2}\right)$ (ATR without ATR correction), Table S1: Crystallographic data for $\mathbf{V 1 2}\left(\mathrm{CH}_{2} \mathrm{NO}_{2}\right)$.

Author Contributions: Conceptualization, Y.K. and Y.H.; methodology, Y.K.; catalytic reaction, Y.K. and H.K.; NMR measurement, H.K.; CSI-MS measurement, Y.K.; crystallization, S.K.; crystal structure determination, Y.K. and S.K.; writing, Y.K. and Y.H.; visualization, Y.K. and H.K.; funding acquisition, Y.K. All authors have read and agreed to the published version of the manuscript.

Funding: This research was funded by JST PRESTO, grant number JPMJPR1655"; Nippon Sheet Glass Foundation for Materials Science and Engineering, JSPS KAKENHI, grant number JP18K14239; and the Core-to-Core Program, and Kanazawa University SAKIGAKE project.

Acknowledgments: The authors thank K. Yamaguchi and K. Suzuki (University of Tokyo) and their co-workers for their help with the CSI-MS measurements.

Conflicts of Interest: The authors declare no conflict of interest.

\section{References}

1. Ikeda, A.; Shinkai, S. Novel Cavity Design Using Calix[n]arene Skeletons: Toward MolecularRecognition and Metal Binding. Chem. Rev. 1997, 97, 1713-1734. [CrossRef] [PubMed]

2. Rebek, J., Jr. Host-guest chemistry of calixarene caplixarene capsules. Chem. Commun. 2000, 637-643. [CrossRef]

3. Blanco-Gómez, A.; Cortón, P.; Neira, L.B.I.; Pazos, E.; Peinador, C.; Garía, M.D. Controlled binding of organic guests by stimuli-responsive macrocycles. Chem. Soc. Rev. 2020, 49, 3834-3862. [CrossRef] [PubMed]

4. Islam, M.; Georghiou, P.E.; Rahman, S.; Yamato, T. Calix[3]arene-Analogous Metacyclophanes: Synthesis, Structures and Properties with Infinite Potential. Molecules 2020, 25, 4202. [CrossRef]

5. Ortolan, A.O.; Øestrøm, I.; Caramori, G.; Parreira, R.L.T.; Muñoz-Castro, A.; Bickelhaupt, F.M. Anion Recognition by Organometallic Calixarenes: Analytsis from Relativistic DFT Calculations. Organometallics 2018, 37, 2167-2176. [CrossRef] 
6. Guo, D.-S.; Liu, Y. Supramolecular Chemistry of $p$-Sulfonatocalix[n]arenes and Its Biological Applications. Acc. Chem. Res. 2014, 47, 1925-1934. [CrossRef]

7. Diamond, D.; McKervey, M.A. Calixarene-based Sensing Agents. Chem. Soc. Rev. 1996, 25, 15-24. [CrossRef]

8. Kumar, R.; Sharma, A.; Singh, H.; Suating, P.; Kim, H.S.; Sunwoo, K.; Shim, I.; Gibb, B.C.; Kim, J.S. Revisiting Fluorescent Calixarenes: From Molecular Sensors to Smart Materials. Chem. Rev. 2019, 119, 9657-9721. [CrossRef]

9. Ma, X.; Zhao, Y. Biomedical Applications of Supramolecular Systems Based on Host-Guest Interactions. Chem. Rev. 2015, 115, 7794-7839. [CrossRef]

10. Homden, D.M.; Redshaw, C. The Use of Calixarenes in Metal-Based Catalysis. Chem. Rev. 2008, 108, 5086-5130. [CrossRef]

11. Ludwing, R. Calixarenes in analytical and separation chemistry. Fresenius J. Anal. Chem. 2000, 367, $103-128$. [CrossRef] [PubMed]

12. Shinkai, S.; Araki, K.; Manabe, O. Does the Calixarene Cavity recognize the Size of Guest Molecules? On the 'Hole-size Selectivity' in Water-soluble Calixarenes. J. Chem. Soc. Chem. Commun. 1988, 187-189. [CrossRef]

13. Hill, C.L. Themed issue on Polyoxometalates. Chem. Rev. 1998, 98, 1-390. [CrossRef] [PubMed]

14. Cronin, L.; Müller, A. Themed issue on Polyoxometalate cluster science. Chem. Soc. Rev. 2012, 41, 7325-7648.

15. Misra, A.; Kozma, K.; Streb, C.; Nyman, M. Beyond Charge Balance: Counter-Cations in Polyoxometalate Chemistry. Angew. Chem. Int. Ed. 2020, 59, 596-612. [CrossRef] [PubMed]

16. Hayashi, Y. Hetero and Lacunary Polyoxovanadate chemistry: Synthesis, reactivity and structural aspects. Coord. Chem. Rev. 2001, 255, 2270-2280. [CrossRef]

17. Streb, C. Polyoxometalate-Based Assemblies and Functional Materials; Song, Y.-F., Ed.; Springer: Cham, Switzerland, 2018; pp. 31-47.

18. Rehder, D. Bioinorganic Vanadium Chemistry; John Wiley \& Sons, Ltd.: Hoboken, NJ, USA, 2008.

19. Day, V.W.; Klemperer, W.G.; Yaghi, O.M. Synthesis and characterization of a soluble oxide inclusion complex, [CH3CN.cntnd.(V12O324-)]. J. Am. Chem. Soc. 1989, 111, 5959-5961. [CrossRef]

20. Klemperer, W.G.; Marquart, T.A.; Yaghi, O.M. Shape-selective binding of nitriles to the inorganic cavitand vanadate, $\mathrm{V}_{12} \mathrm{O}_{32}{ }^{4-}$. Mater. Chem. Phys. 1991, 29, 97-104. [CrossRef]

21. Rohmer, M.-M.; Benard, M. An Interpretation of the Structure of the Inclusion Complexes $\left[\mathrm{RCN} \subset\left(\mathrm{V}_{12} \mathrm{O}_{32}\right)^{4-}\right]$ $\left(\mathrm{R}=\mathrm{CH}_{3}, \mathrm{C}_{6} \mathrm{H}_{5}\right)$ from Electrostatic Potentials. J. Am. Chem. Soc. 1994, 116, 6959-6960. [CrossRef]

22. Rohmer, M.-M.; Devemy, J.; Wiest, R.; Benard, M. Ab Initio Modeling of the Endohedral Reactivity of Polyoxometallates: 1. Host-Guest Interactions in $\left[\mathrm{RCN} \subset\left(\mathrm{V}_{12} \mathrm{O}_{32}\right)^{4-}\right]\left(\mathrm{R}=\mathrm{H}, \mathrm{CH}_{3}, \mathrm{C}_{6} \mathrm{H}_{5}\right)$. J. Am. Chem. Soc. 1996, 118, 13007-13014. [CrossRef]

23. Kurata, T.; Hayashi, Y.; Isobe, K. Synthesis and characterization of chloride-incorporated dodecavanadate from dicopper complex of macrocyclic octadecavanadate. Chem. Lett. 2010, 39, 708-709. [CrossRef]

24. Inoue, Y.; Kikukawa, Y.; Kuwajima, S.; Hayashi, Y. A chloride capturing system via proton-induced structure transformation between opened- and closed-forms of dodecavanadates. Dalton Trans. 2016, 45, 7563-7569. [CrossRef] [PubMed]

25. Kuwajima, S.; Ikinobu, Y.; Watanabe, D.; Kikukawa, Y.; Hayashi, Y.; Yagasaki, A. A Bowl-Type Dodecavanadate as a Halide Receptor. ACS Omega 2017, 2, 268-275. [CrossRef] [PubMed]

26. Kuwajima, S.; Kikukawa, Y.; Hayashi, Y. Small-Molecule Anion Recognition by a Shape-Responsive Bowl-Type Dodecavanadate. Chem. Asian J. Chem. 2017, 12, 1909-1914. [CrossRef]

27. Kuwajima, S.; Arai, Y.; Kitajima, H.; Kikukawa, Y.; Hayashi, Y. Synthesis and structural characterization of tube-type tetradecavanadates. Acta Crystallogr. C 2018, 74, 1295-1299.

28. Kikukawa, Y.; Seto, K.; Uchida, S.; Kuwajima, S.; Hayashi, Y. Solid-State Umbrella-type Inversion of a $\mathrm{VO}_{5}$ Square-Pyramidal Unit in a Bowl-type Dodecavanadate Induced by Insertion and Elimination of a Guest Molecule. Angew. Chem. Int. Ed. 2018, 57, 16051-16055. [CrossRef] [PubMed]

29. Kikukawa, Y.; Seto, K.; Watanabe, D.; Kitajima, H.; Katayama, M.; Yamashita, S.; Inada, Y.; Hayashi, Y. Induced Fitting and Polarization of a Bromine Molecule in an Electrophilic Inorganic Molecular Cavity and Its Bromination Reactivity. Angew. Chem. Int. Ed. 2020, 59, 14399-14403. [CrossRef]

30. Kawanami, N.; Ozeki, T.; Yagasaki, A. NO-Anion Trapped in a Molecular Oxide Bowl. J. Am. Chem. Soc. 2000, 122, 1239-1240. [CrossRef]

31. North, M.; Omedes-Pujol, M.; Yong, C. Kinetics and mechanism of the racemic addition of trimethylsilyl cyanide to aldehydes catalysed by Lewis bases. Org. Biomol. Chem. 2012, 10, 4289-4298. [CrossRef] 
32. Holmes, B.T.; Arthur, S.W. Aliphatic thioacetate deprotection using catalytic tetrabutylammonium cyanide. Tetrahedron 2005, 61, 12339-12342. [CrossRef]

33. Park, H.J.; Lee, S.S. Catalytic Deacetylation of p-Nitrophenyl Thioacetate by Cyanide Ion and Its Sensor Applications. Anal. Sci. 2019, 35, 589-593. [CrossRef] [PubMed]

34. Miyashita, A.; Numata, A.; Suzuki, Y.; Iwamoto, K.; Higashino, T. Olefin-Insertion Raction between the Carbonyls of Benzils; Formation of 1,4-Diketones by Michael Addition Catalyzed by Cyanide Ion. Chem. Lett. 1997, 24, 697-698. [CrossRef]

35. Ullah, B.; Chen, J.; Zhang, Z.; Xing, H.; Yang, Q.; Bao, Z.; Ren, Q. 1-Ethyl-3-methylimidazolium acetate as a highly efficient organocatalyst for cyanosilylation of carbonyl compounds with trimethylsilyl cyanide. Sci. Rep. 2017, 7, 42699. [CrossRef] [PubMed]

36. Huang, X.; Chen, L.; Ren, F.; Yang, C.; Li, J.; Shi, K.; Gou, X.; Wang, W. Lewis Acid Rather than Brønsted Acid Sites of Montmorillonite K10 Act as a Powerful and Reusable Green Heterogeneous Catalyst for Rapid Cyanosilylation of Ketones. Synlett 2017, 28, 439-444. [CrossRef]

37. Wang, W.; Wang, X.; Zhou, S.; Xu, X.; Du, J.; Zhang, L.; Mu, X.; Wei, Y.; Zhu, X.; Wang, S. Syntheses, Structures, and Catalytic Activities of the Anionic Heterobimetallic Rare-Earth Metal Complexes Supported by Pyrrolyl-Substituted 1,2-Diimino Ligands. Inorg. Chem. 2018, 57, 10390-10400. [CrossRef]

38. Rawat, S.; Bhandari, M.; Prashanth, B.; Singh, S. Three Coordinated Organoaluminum Cation for Rapid and Selective Cyanosilylation of Carbonyls under Solvent-Free Conditions. ChemCatChem 2020, 12, 2407-2411. [CrossRef]

39. Jameson, C.J.; Rehder, D.; Hoch, M. Isotope and Temperature Dependence of Transition-Metal Shielding in Complexes of the Type M(XY) 6 . J. Am. Chem. Soc. 1987, 109, 2589-2594. [CrossRef]

40. Griswold, A.A.; Starcher, P.S. The Nuclear Magnetic Resonance Spectra of aci-Nitro Anions. J. Org. Chem. 1965, 30, 1687-1690. [CrossRef]

41. Engelke, R.; Earl, W.L.; Rohlfing, C.M. Production of the Ntromethane Acl Ion by UV Irradiation: Its Effect on Detonation Sensitivity. J. Phys. Chem. 1986, 90, 545-547. [CrossRef]

42. APEX3, SAINT, and SADABS; Bruker AXS Inc.: Madison, WI, USA, 2015.

43. Farrugia, L.J. WinGX suite for small-molecule single-crystal crystallography. J. Appl. Crystallogr. 1999, 32, 837-838. [CrossRef]

44. Gruene, T.; Hahn, H.W.; Luebben, A.V.; Sheldrick, G.M. Refinement of macromolecular structures against neutron data with SHELXL2013. J. Acta Cryst. 2014, 47, 462-466.

Sample Availability: Samples of the compounds are available from the authors.

Publisher's Note: MDPI stays neutral with regard to jurisdictional claims in published maps and institutional affiliations.

(C) 2020 by the authors. Licensee MDPI, Basel, Switzerland. This article is an open access article distributed under the terms and conditions of the Creative Commons Attribution (CC BY) license (http://creativecommons.org/licenses/by/4.0/). 